\title{
Perinatal Risk and Protective Factors in the Development of Diffuse White Matter Abnormality on Term-Equivalent Age MRI in Infants Born Very Preterm
}

Nehal A. Parikh, DO, MS ${ }^{1,2 \star}$, Puneet Sharma, MD ${ }^{1,2}$, Lili He, $\mathrm{PhD}^{1,2}$, Hailong Li, $\mathrm{PhD}^{1}$, Mekibib Altaye, $\mathrm{PhD}^{2,3}$, and Venkata Sita Priyanka Illapani, $\mathrm{MS}^{1}$ for the Cincinnati Imaging \& Neurodevelopment Early Prediction Study (CINEPS)

${ }^{1}$ The Perinatal Institute, Cincinnati Children's Hospital Medical Center, United States ${ }^{2}$ Department of Pediatrics, University of Cincinnati, College of Medicine United States ${ }^{3}$ Division of Biostatistics and Epidemiology, Cincinnati Children's Hospital Medical Center, United States

${ }^{*}$ Correspondence:

Nehal A. Parikh, DO, MS

Professor of Pediatrics

Cincinnati Children's Hospital Medical Center, 3333 Burnet Avenue, MLC 4009

Cincinnati, $\mathrm{OH}, 45229$, United States

Email: nehal.parikh@cchmc.org

Phone number: 513.803 .7884 
medRxiv preprint doi: https://doi.org/10.1101/2020.08.01.20166488; this version posted August 4, 2020. The copyright holder for this preprint (which was not certified by peer review) is the author/funder, who has granted medRxiv a license to display the preprint in perpetuity.

All rights reserved. No reuse allowed without permission.

\section{Key Points}

Question: What perinatal clinical factors are independently associated with the development of diffuse white matter abnormality (DWMA) in very preterm infants?

Findings: In this prospective cohort study, pneumothorax, severe bronchopulmonary dysplasia (BPD), severe retinopathy of prematurity, and male sex were significantly associated with an increased risk of DWMA. Significant protective factors included dexamethasone for severe BPD, duration of caffeine for severe BPD, and exclusive maternal milk diet at NICU discharge.

Meaning: Knowledge of these common and modifiable neonatal diseases and treatments may allow clinicians to reduce the burden of DWMA development through targeted prevention or treatments approaches. 


\section{Abstract}

Importance: Diffuse white matter abnormality (DWMA) is the most common brain MRI finding in very preterm infants and is predictive of neurodevelopmental impairments. However, its etiology remains elusive and identifying perinatal risk and protective factors may allow clinicians to reduce the burden of DWMA.

Objective: To identify perinatal clinical factors that are associated with the development of objectively diagnosed DWMA in very preterm infants.

Design: A prospective cohort was enrolled between September 2016 and November 2019. Brain MRls were collected at 39 to 45 weeks postmenstrual age (PMA) to evaluate DWMA volume. A pre-defined list of pertinent maternal characteristics, pregnancy/delivery data, and neonatal ICU data was collected for enrolled patients to identify antecedents of objectively diagnosed DWMA.

Setting: Five level III/IV NICUs in the greater Cincinnati, Ohio area.

Participants: A population-based sample of 392 very preterm infants born before 33 weeks gestational age.

Exposure: Very preterm birth with associated diseases and treatments.

Main Outcome and Measure: Objectively diagnosed DWMA volume on brain MRI at termequivalent age.

Results: 377 of the 392 very preterm infants (96\%) had high quality MRI data. Mean (SD) gestational age was 29.3 (2.5) weeks. In multivariable linear regression analyses, pneumothorax $(p=.027)$, severe bronchopulmonary dysplasia (BPD) $(p=.009)$, severe retinopathy of prematurity (ROP) $(p<0.001)$, and male sex $(p=.041)$ were associated with 
medRxiv preprint doi: https://doi.org/10.1101/2020.08.01.20166488; this version posted August 4, 2020. The copyright holder for this preprint (which was not certified by peer review) is the author/funder, who has granted medRxiv a license to display the preprint in perpetuity.

All rights reserved. No reuse allowed without permission.

increasing volume of DWMA. The following factors were associated with decreased risk of DWMA - dexamethasone for severe BPD $(p=.004)$, duration of caffeine for severe BPD $(p=$ 0.009), and exclusive maternal milk at NICU discharge $(p=.049)$.

Conclusions and Relevance: Severe ROP and BPD exhibited the strongest adverse association with the development of DWMA. Caffeine and dexamethasone treatments for infants with severe BPD exhibited a protective effect against development of DWMA. The beneficial association with maternal milk is also a modifiable factor that has clinical implications. 
medRxiv preprint doi: https://doi.org/10.1101/2020.08.01.20166488; this version posted August 4, 2020. The copyright holder for this preprint (which was not certified by peer review) is the author/funder, who has granted medRxiv a license to display the preprint in perpetuity.

All rights reserved. No reuse allowed without permission.

\section{Introduction}

Improvements in the care of preterm infants have resulted in fewer instances of severe injury such as periventricular leukomalacia (PVL) and intraventricular hemorrhage $\left.(\mathrm{IVH})^{1}\right]$. Even so, the prevalence of neurodevelopmental impairment (NDI) remains unacceptably high ${ }^{2,3}$. Brain MRI studies in preterm infants have identified diffuse, subtle abnormalities in brain maturation and signal abnormality that may be the modern antecedents of $\mathrm{NDI}^{4-8}$ ]. Diffuse excessive high signal intensity (DEHSI) is defined as the presence of higher than normal signal intensity in the developing white matter, as seen on $\mathrm{T}^{2}$-weighted $\mathrm{MRI}^{1}$. It is detected in $50-80 \%$ of $\mathrm{MRI}$ scans of very preterm infants at approximately term-equivalent age ${ }^{9}$. Detailed diffusion MRI studies have identified a complex set of white matter microstructural abnormalities in areas of the brain affected by DEHSI ${ }^{10,11}$. The only post-mortem analysis of infants with DEHSI identified pathology consistent with PVL, such as microgliosis and astrocytosis, in addition to distinct findings such as diffuse vacuolations ${ }^{12}$. It remains unclear if DEHSI represents a milder form of PVL, because of evidence of diffuse injury without necrosis on post-mortem histology, or a distinct abnormality ${ }^{13,14}$.

Despite these pathological radiographic and histologic findings, only a few studies have explored which perinatal clinical factors contribute to the development of DEHSI, in order to further our understanding of this prevalent signal abnormality ${ }^{1,9,10,15,16}$. In one study, surgical ligation of patent ductus arteriosus (PDA) was identified as a potential risk factor for $\mathrm{DEHSI}{ }^{10}$. Several other studies could not identify any antecedents of DEHSI; however, these studies were likely underpowered ${ }^{1,9,15}$. Additionally, these negative results may have stemmed from qualitative diagnosis of DEHSI, which is subjective and cannot be made with high reliability ${ }^{17-19}$. This motivated us to develop automated algorithms to objectively quantify DEHSI ${ }^{20,21}$. We refer to DEHSI, when objectively diagnosed, as diffuse white matter abnormality (DWMA). It is defined as the total volume of white matter exhibiting elevated signal intensity (details below) as 
medRxiv preprint doi: https://doi.org/10.1101/2020.08.01.20166488; this version posted August 4, 2020. The copyright holder for this preprint (which was not certified by peer review) is the author/funder, who has granted medRxiv a license to display the preprint in perpetuity.

All rights reserved. No reuse allowed without permission.

compared to the surrounding white matter on term T2-weighted $\mathrm{MRI}^{20,21}$. In two prior studies we correlated DEHSI and objectively diagnosed DWMA at term with NDI at age 2 and found that DWMA was significantly correlated with cognitive and language development, whereas DEHSI was not ${ }^{6,8}$.

Previously, we identified severe retinopathy of prematurity (ROP) and severe bronchopulmonary dysplasia (BPD) as antecedent risk factors of objectively diagnosed DWMA ${ }^{16,22}$. However, these prior studies lacked sufficient power to examine less common antecedent factors and common pathophysiologic pathways (e.g. inflammation). Our objective was to identify antenatal and neonatal clinical factors that are independently associated with the development of objectively diagnosed DWMA at term in a large geographically-defined cohort of very preterm infants. We hypothesized that several modifiable clinical antecedent factors would be associated with the development of DWMA, as diagnosed on term MRI. 


\section{Designs \& Methods}

\section{Subjects}

We enrolled a multicenter prospective cohort of 392 very preterm infants from five neonatal intensive care units (NICU) in the greater Cincinnati area. This included all four academic and community level III/IV NICUs in Cincinnati: 1) Cincinnati Children’s Hospital Medical Center (CCHMC), the primary academic referral center for high-risk neonates; 2) University of Cincinnati Medical Center, the primary academic referral center for high-risk pregnancies; 3) Good Samaritan Hospital; 4) St. Elizabeth's Healthcare; and one community level III NICU in Dayton, Ohio, Kettering Medical Center. All very preterm infants - born at or before 32 weeks gestational age (GA) - who were cared for in one of these NICUs between September 2016 and November 2019 were eligible for inclusion. Infants were excluded if they met any of the following criteria: 1) known chromosomal or congenital anomalies affecting the central nervous system; 2) cyanotic heart disease; or 3) hospitalization and mechanical ventilation with greater than $50 \%$ supplemental oxygen at 45 weeks postmenstrual age (PMA). The Cincinnati Children's Hospital Institutional Review Board approved the study, and the review boards of the other hospitals approved the study based on an established reliance agreement. Written informed consent was given by a parent or guardian of each study infant, after they were given at least 24 hours in which to review the consent and ask questions of the investigators.

Information about MRI data acquisition ${ }^{23}$, objective DWMA quantification ${ }^{21,24}$, and structural MRI scoring $^{23,25}$ are previously described and summarized in the Supplementary Appendix.

\section{Clinical antecedents}

Trained research staff collected a pre-defined list of maternal characteristics, pregnancy/delivery data, and infant data beginning at birth and ending at NICU discharge or study MRI examination, whichever occurred first. All variables were as previously defined (Supplementary 
medRxiv preprint doi: https://doi.org/10.1101/2020.08.01.20166488; this version posted August 4, 2020. The copyright holder for this preprint (which was not certified by peer review) is the author/funder, who has granted medRxiv a license to display the preprint in perpetuity.

All rights reserved. No reuse allowed without permission.

Appendix $)^{16}$. We could not examine the effect of surgical ligation for PDA, as this was performed in only three subjects. All brain MRI scans were read by a pediatric neuroradiologist as previously described $^{23}$, using an established neonatal MRI quantification system to derive a global abnormality score ${ }^{25}$.

\section{Statistical analysis}

DWMA volume data was skewed and was thus transformed by taking its cubic root. As described previously ${ }^{16}$, we examined the association between approximately 50 antenatal, intrapartum, and postnatal clinical factors with normalized DWMA volume in bivariate linear regression analyses. Variables that were correlated with DWMA volume $(p<0.10)$ in bivariate analyses were entered into a multivariable linear regression model in a manual backward stepwise fashion, to evaluate their independent association with DWMA. In addition, we used knowledge of prior literature and biological plausibility to guide variable selection. Because postnatal covariates can overshadow antepartum or intrapartum variables that may be causative, we created multivariable regression models in which we ordered clinical factors temporally, so that the earliest occurring factors were entered first and could not be displaced by later occurring covariates ${ }^{16,26}$.

To control for variation in clinical care practices between the five NICUs, we included NICU/Center as a covariate in the final model. Main effects and interactions were evaluated. All analyses were adjusted for postmenstrual age at MRI scan. Two-sided $p$ values $<0.05$ were considered to indicate statistical significance. We performed all analyses using STATA 16.0 (Stata Corp., College Station, TX). 
medRxiv preprint doi: https://doi.org/10.1101/2020.08.01.20166488; this version posted August 4, 2020. The copyright holder for this preprint (which was not certified by peer review) is the author/funder, who has granted medRxiv a license to display the preprint in perpetuity.

All rights reserved. No reuse allowed without permission.

\section{Results}

Of the original cohort of 392 infants, 15 could not be accurately segmented, eight because of excessive motion artifacts and seven due to moderate-severe ventriculomegaly/brain injury. Therefore, accurate DWMA data was available for 377 infants (96\%). The mean (SD) gestational age was 29.31 (2.50) weeks. Table 1 summarizes key baseline antepartum, intrapartum, and postnatal maternal and infant clinical characteristics for our final cohort. In bivariate analyses (as a first step for selecting candidate variables for the multivariate model), adjusting for PMA at MRI scan, several antecedents were associated with normalized DWMA volume $(p<.10)$, including maternal progesterone therapy $(p=.053)$, male sex $(p=.069)$, pneumothorax $(p=.030)$, prophylactic indomethacin $(p<.001)$, cyclooxygenase inhibitor therapy (ibuprofen/indomethacin) for PDA ( $p=.004)$, any BPD $(p=.086)$, severe BPD $(p=.041)$, postnatal dexamethasone for BPD $(p<.001)$, duration of caffeine therapy $(p=.085)$, severe ROP $(p=.042)$, surgery requiring general anesthesia $(p=.073)$, white matter abnormality score $(p=.002)$, and NICU/Center $(p=.014)$. Additionally, we identified a significant interaction between postnatal dexamethasone therapy and severe BPD $(p<.001)$ and between duration of caffeine therapy and severe BPD $(p=.006)$.

In multivariable linear regression analyses, controlling for PMA at MRI scan and NICU/Center, several postnatal variables remained significant in the final model, including infant sex, pneumothorax, severe ROP, severe BPD, postnatal dexamethasone for severe BPD (interaction term), duration of caffeine therapy for severe BPD (interaction term), exclusive maternal breast milk nutrition at NICU discharge, and white matter abnormality score (Table 2). Both severe ROP and severe BPD increased the risk of DWMA. Conversely, postnatal steroid and caffeine therapy for severe BPD reduced the risk of DWMA (Table 2). The addition of gestational age $(p=.854)$ did not change the significance of the other variables in the final model. Replacing our primary outcome variable - DWMA volume normalized by white matter 
medRxiv preprint doi: https://doi.org/10.1101/2020.08.01.20166488; this version posted August 4, 2020. The copyright holder for this preprint (which was not certified by peer review) is the author/funder, who has granted medRxiv a license to display the preprint in perpetuity.

All rights reserved. No reuse allowed without permission.

volume - with either DWMA volume normalized by combined white and gray matter volume or uncorrected DWMA volume did not change the significance level or regression parameters of the covariates by more than $5 \%$.

Of the 65 infants with severe BPD, 39 were treated with postnatal dexamethasone, all using the published Dexamethasone A Randomized Trial (DART) protocol, which results in a cumulative dosing of $0.89 \mathrm{mg} / \mathrm{kg}$ of dexamethasone administered over 10 days $\mathrm{s}^{27}$. Nine of these infants received a second course of DART, and one infant received three total courses. The median (range) duration of caffeine therapy was $62(0-89)$ days for infants with severe BPD. At NICU discharge or study MRI, whichever came first, 42 (11.1\%) were receiving their mother's breast milk exclusively, 165 (43.8\%) were receiving a combination of mother's milk and preterm infant formula, and the remaining 170 (45.1\%) were exclusively receiving infant formula. Replacing exclusive mother's milk in the model with exclusive formula at discharge resulted in a beta coefficient of $.01431(95 \% \mathrm{Cl}:-.00036, .02898 ; p=.056)$, which represents a significant trend towards an opposite effect on DWMA volume.

We did not find a significant relationship in bivariate or multivariable analyses between DWMA and any of the following key clinical variables: antenatal corticosteroid therapy, antenatal magnesium therapy, clinical or histologic chorioamnionitis, delayed cord clamping, low 5-minute Apgar score, transitional hypotension, PDA, sepsis, antibiotics, necrotizing enterocolitis, or duration of total parenteral nutrition. 
medRxiv preprint doi: https://doi.org/10.1101/2020.08.01.20166488; this version posted August 4, 2020. The copyright holder for this preprint (which was not certified by peer review) is the author/funder, who has granted medRxiv a license to display the preprint in perpetuity.

All rights reserved. No reuse allowed without permission.

\section{Discussion}

Studying a well-characterized and geographically-defined cohort of very preterm infants, we identified several new independent perinatal clinical factors that antecede the development of DWMA at term-equivalent age. We also externally validated the previously-reported association between both severe ROP and severe BPD and increased DWMA volume ${ }^{16}$. These two diseases exhibited the largest effect on DWMA volume. Interestingly, postnatal dexamethasone therapy and caffeine therapy, the two most effective drugs for reducing BPD risk, were associated with a decreased DWMA risk when administered to very preterm infants with severe BPD. These novel associations have not been reported previously. They further strengthen the adverse association between severe BPD and DWMA. Pneumothorax and an exclusive diet of maternal milk represent two additional factors that have not been previously reported. Each of the new antecedents we uncovered has been associated with NDI, but the way in which they are mediated by early brain development/injury has not been fully delineated.

This is the third study to identify severe ROP as a key risk factor for DWMA ${ }^{16,22}$. Development of severe ROP is among the most prominent neonatal risk factors for NDI, independent of structural injury on cranial ultrasound ${ }^{28,29}$. Even qualitative structural MRI studies have not been able to mechanistically explain this association. Recently, we identified a negative association between ROP and automatically-quantified sulcal depth, a measure of brain maturation, on term $\mathrm{MRI}^{30}$. The association with DWMA suggests an additional mechanism by which ROP is causally associated with $\mathrm{NDI}^{28,29}$.

Similar to severe ROP, we previously reported a robust association between severe BPD and DWMA in a separate independent cohort ${ }^{16}$. Unlike this prior report, which was likely underpowered for less common conditions/treatments, in our current study we identified an interaction between severe BPD and postnatal dexamethasone therapy and an interaction 
medRxiv preprint doi: https://doi.org/10.1101/2020.08.01.20166488; this version posted August 4, 2020. The copyright holder for this preprint (which was not certified by peer review) is the author/funder, who has granted medRxiv a license to display the preprint in perpetuity.

All rights reserved. No reuse allowed without permission.

between severe BPD and duration of caffeine therapy, both of which were associated with reduced DWMA volume. These findings are highly relevant for the clinical care of very preterm infants as they contribute to our understanding of how these drugs may improve long-term neurodevelopmental outcomes, particularly when administered to infants at high risk for severe BPD. For example, postnatal dexamethasone use, even at the relatively low doses used in our population (e.g. DART protocol ${ }^{27}$ ), has remained low since 2003, when the American Academy of Pediatrics recommended a moratorium due to concerns regarding NDI following dexamethasone therapy ${ }^{31}$. However, it soon become clear that NDI occurred primarily in treated infants at low baseline risk of BPD ( $<50 \%)$, typically during the first week of age, when such risk is difficult to estimate ${ }^{32}$. Conversely, treatment of infants at high baseline risk of BPD (>50-67\%) results in a lower risk of cerebral palsy or death. Our finding of an association between dexamethasone treatment in infants with severe BPD and DWMA development suggests a beneficial mechanism of this corticosteroid. Dexamethasone may act on the brain either directly via an anti-inflammatory effect (e.g. reduced cerebral edema) or indirectly by reducing BPD severity. Our novel findings supports the use of low dose dexamethasone for the prevention of DWMA and potentially NDI in infants with severe BPD.

The association of DWMA with duration of caffeine therapy in infants with severe BPD suggests that the proven long-term beneficial effects of caffeine on motor development ${ }^{33}$ in very preterm infants may be mediated through an early neuroprotective effect on DWMA development. Mechanistically, this benefit may be directly mediated by caffeine's weak diuretic effects, via protection against intermittent hypoxemia ${ }^{34}$, and/or through adenosine receptor blockage and secondary anti-inflammatory effects ${ }^{35,36}$. Conversely, it may act indirectly by reducing the risk of $\mathrm{BPD}^{37}$. Our novel findings suggest that DWMA volume could potentially be used as a surrogate outcome measure in quality improvement efforts or new randomized trials, in order to assess 
medRxiv preprint doi: https://doi.org/10.1101/2020.08.01.20166488; this version posted August 4, 2020. The copyright holder for this preprint (which was not certified by peer review) is the author/funder, who has granted medRxiv a license to display the preprint in perpetuity.

All rights reserved. No reuse allowed without permission.

the expanded use of new therapeutic dosing of caffeine or dexamethasone in infants with severe BPD.

The cognitive benefits of human milk in preterm infants were demonstrated in a meta-analysis of 11 cohort studies with short-term outcomes ${ }^{38}$ and in studies of preterm infants at school age and in adolescence ${ }^{39-41}$. We identified a significant protective effect of an exclusive maternal milk diet during the NICU period on DWMA development at term. Conversely, an exclusive formula diet at NICU discharge exhibited a trend towards higher DWMA volume, and a mixed human milk and formula diet exhibited an intermediate effect $(p=0.49)$. These findings have not been reported previously and add to our growing understanding of the neuronal mechanisms by which maternal milk confers neurocognitive benefits. In quantitative MRI studies, Pogribna et al. ${ }^{42}$ identified dose-dependent improved microstructural maturation of the corpus callosum at term in breast milk-fed infants, while Belsa et al. ${ }^{43}$ reported significant benefits on the corpus callosum and several other white matter regions, including the periventricular white matter, in a smaller cohort of very preterm infants. Other studies have noted increased regional brain volumes, such as deep nuclear gray matter at term ${ }^{40}$ and total white matter in adolescence, in subjects who were predominantly fed maternal milk during the NICU period ${ }^{41}$.

No prior studies have identified an association between neonatal pneumothorax and the development of DWMA. However, several studies in preterm infants have identified an association between pneumothorax and an increased risk of severe $\mathrm{IVH}^{44-46}$. In a cohort of 803 very low birth weight infants, pneumothorax was significantly associated with lower odds of survival without severe IVH and/or $\mathrm{PVL}^{46}$. While the link between severe IVH on ultrasound and neurodevelopmental deficits is well-established, one large cohort study of 1749 extremely low birth weight infants with normal head ultrasound also identified an independent relationship between pneumothorax and cerebral palsy, suggesting other mechanisms by which 
medRxiv preprint doi: https://doi.org/10.1101/2020.08.01.20166488; this version posted August 4, 2020. The copyright holder for this preprint (which was not certified by peer review) is the author/funder, who has granted medRxiv a license to display the preprint in perpetuity.

All rights reserved. No reuse allowed without permission.

pneumothorax adversely affects neurodevelopment ${ }^{47}$. Acute pneumothorax results in acute hypoxemia and hypercapnia in newborns, and in experimental models it can cause cytotoxic cerebral edema ${ }^{48}$. The presence of a tension pneumothorax additionally compromises cardiac output, which limits the hypoxia/hypercarbia-mediated increase in perfusion to the brain and heart $^{49}$. Less severe cases of pneumothorax that do not result in tension and/or cardiovascular compromise may still result in neuronal injury and secondary edema that manifest as diffuse excessive high signal intensity abnormality on term MRI.

The bright signal abnormalities that are the hallmark of DWMA begin to decrease between 42 and 50 weeks $P M A^{50}$. We found a similar pattern of decrease in DWMA with advancing age at MRI scan. Interestingly, we also observed a negative association between objectively-defined DWMA and a semi-quantitative measure of WM injury/abnormality. This association has not been previously reported and suggests that other white matter abnormalities/injuries may result from factors different that those associated with DWMA. Importantly, as with white matter abnormalities such as PVL and ventriculomegaly, objectively-defined DWMA is predictive of cognitive and language deficits, a finding that has now been reported in two independent cohorts of preterm infants ${ }^{6,8}$.

Both ROP and BPD share systemic inflammation, hypoxia, and hyperoxia as common mechanisms that could directly or indirectly result in brain injury. In addition to the well-known risk factors of hypoxia and hyperoxia, recent evidence from large epidemiologic investigations and experimental models implicate antenatal inflammation and postnatal infection/inflammation as strong risk factors for the development of $\mathrm{ROP}^{51-55}$. The large reduction in BPD incidence noted in randomized trials of postnatal corticosteroids and the lack of benefit observed following antioxidant therapies or tighter control of oxygen saturation, suggests that inflammation may be a significant causal factor in the development of $\mathrm{BPD}^{56-60}$. Our findings of reduced DWMA 
following treatment with dexamethasone, a potent anti-inflammatory drug, and caffeine ${ }^{35,36}$, further supports inflammation as a key mechanism in the development of DWMA. Conversely, we did not observe an association between DWMA and other pro-inflammatory conditions such as chorioamnionitis or postnatal sepsis. Human milk also has anti-inflammatory properties, as it contains molecules such as secretory immunoglobulin A, transforming growth factor beta, lactoferrin, and interleukin-10 that can protect the newborn against inflammation ${ }^{61,62}$. We also did not find an association with delayed cord clamping, low Apgar scores, transitional hypotension, or PDA, factors more closely associated with hypoxia-ischemia, suggesting that this may not be the predominant underlying mechanism in the development of DWMA.

The strengths of our study include a robust, geographically-based cohort, the use of an objective, validated algorithm to diagnose DWMA, and comprehensive examination of important perinatal variables known to be associated with NDI. Our study also has several weaknesses. We did not collect serum biomarkers of inflammation, hypoxia, or ischemia to further elucidate the molecular mechanisms underlying DWMA development. The rates of PDA ligation and surgery for NEC or SIP were low, and therefore we may have been underpowered to examine their associations with DWMA. Finally, our findings should only be viewed as associations rather than primary causes. Nevertheless, this study represents the largest and most rigorous examination of the antecedents of DWMA development in very preterm infants. The significant relationship between these novel antecedent factors and DWMA enhances our understanding of the mechanisms of their known adverse/protective effects on NDI. It further suggests that quality improvement and research interventions that target reduced rates of ROP, pneumothorax, and BPD, e.g. with increased targeted use of dexamethasone and/or caffeine, may result in a lower burden of DWMA and subsequently in reduced rates of NDI. 


\section{Acknowledgements}

This research was supported by National Institutes of Health grants R01-NS094200-05 and R01-NS096037-03 from the National Institute of Neurological Disorders and Stroke (NINDS). The content is solely the responsibility of the authors and does not necessarily represent the official views of NINDS or the National Institutes of Health. We sincerely thank the Cincinnati Imaging \& Neurodevelopment Early Prediction Study (CINEPS) Investigators: Principal Investigator: Nehal A. Parikh, D.O., MS. Collaborators (in alphabetical order): Mekibib Altaye, Ph.D., Anita Arnsperger, RRT, Traci Beiersdorfer, RN BSN, Kaley Bridgewater, RT(M.R.) CNMT, Tanya Cahill, MD, Kim Cecil, Ph.D., Kent Dietrich, RT, Christen Distler, BSN RNC-NIC, Juanita Dudley, RN BSN, Brianne Georg, BS, Cathy Grisby, RN BSN CCRC, Lacey Haas, RT(M.R.) CNMT, Karen Harpster, Ph.D., OT/RL, Lili He, Ph.D., Scott K. Holland, Ph.D., V.S. Priyanka Illapani, MS, Kristin Kirker, CRC, Julia E. Kline, Ph.D., Beth M. Kline-Fath, MD, Hailong Li, Ph.D., Matt Lanier, RT(M.R.) R.T. (R), Stephanie L. Merhar, MD MS, Greg Muthig, BS, Brenda B. Poindexter, MD MS, David Russell, JD, Kari Tepe, BSN RNC-NIC, Leanne Tamm, Ph.D., Julia Thompson, RN BSN, Jean A. Tkach, Ph.D., Sara Stacey, BA, Jinghua Wang, Ph.D., Brynne Williams, RT(M.R.) CNMT, Kelsey Wineland, RT(M.R.) CNMT, Sandra Wuertz, RN BSN CCRP, Donna Wuest, AS, Weihong Yuan, Ph.D. We also greatly appreciate the support of our NICU fellows, nurses, and staff, and, most importantly, all the study families that made this research possible. 


\section{References}

1. Jeon TY, Kim JH, Yoo SY, et al. Neurodevelopmental outcomes in preterm infants: comparison of infants with and without diffuse excessive high signal intensity on MR images at near-term-equivalent age. Radiology. 2012;263(2):518-526.

2. Torchin H, Morgan AS, Ancel P-Y. International comparisons of neurodevelopmental outcomes in infants born very preterm. Seminars in Fetal and Neonatal Medicine. 2020;25(3):101109.

3. Pascal A, Govaert P, Oostra A, Naulaers G, Ortibus E, Van den Broeck C. Neurodevelopmental outcome in very preterm and very-low-birthweight infants born over the past decade: a meta-analytic review. Dev Med Child Neurol. 2018;60(4):342-355.

4. Engelhardt E, Inder TE, Alexopoulos D, et al. Regional impairments of cortical folding in premature infants. Ann Neurol. 2015;77(1):154-162.

5. Kline JE, Illapani VSP, He L, Altaye M, Logan JW, Parikh NA. Early cortical maturation predicts neurodevelopment in very preterm infants. Arch Dis Child Fetal Neonatal Ed. 2019. 6. Parikh NA, He L, Bonfante-Mejia E, et al. Automatically quantified diffuse excessive high signal intensity on MRI predicts cognitive development in preterm infants. Pediatr Neurol. $2013 ; 49(6): 424-430$.

7. Cayam-Rand D, Guo T, Grunau RE, et al. Predicting developmental outcomes in preterm infants: A simple white matter injury imaging rule. Neurology. 2019;93(13):e1231e1240.

8. Parikh NA, He L, Priyanka Illapani VS, Altaye M, Folger AT, Yeates KO. Objectively Diagnosed Diffuse White Matter Abnormality at Term Is an Independent Predictor of Cognitive and Language Outcomes in Infants Born Very Preterm. J Pediatr. 2020;220:56-63.

9. Brostrom L, Bolk J, Padilla N, et al. Clinical Implications of Diffuse Excessive High Signal Intensity (DEHSI) on Neonatal MRI in School Age Children Born Extremely Preterm. PLoS One. 2016;11(2):e0149578. 
10. Skiold B, Horsch S, Hallberg B, et al. White matter changes in extremely preterm infants, a population-based diffusion tensor imaging study. Acta Paediatr. 2010;99(6):842-849.

11. Counsell SJ, Shen Y, Boardman JP, et al. Axial and radial diffusivity in preterm infants who have diffuse white matter changes on magnetic resonance imaging at term-equivalent age. Pediatrics. 2006;117(2):376-386.

12. Parikh NA, Pierson CR, Rusin JA. Neuropathology Associated With Diffuse Excessive High Signal Intensity Abnormalities on Magnetic Resonance Imaging in Very Preterm Infants. Pediatr Neurol. 2016;65:78-85.

13. Back SA. White matter injury in the preterm infant: pathology and mechanisms. Acta Neuropathol. 2017;134(3):331-349.

14. Volpe JJ. Dysmaturation of Premature Brain: Importance, Cellular Mechanisms, and Potential Interventions. Pediatr Neurol. 2019;95:42-66.

15. Murner-Lavanchy IM, Kidokoro H, Thompson DK, et al. Thirteen-Year Outcomes in Very Preterm Children Associated with Diffuse Excessive High Signal Intensity on Neonatal Magnetic Resonance Imaging. J Pediatr. 2019;206:66-71 e61.

16. Parikh NA, He L, Li H, Priyanka Illapani VS, Klebanoff MA. Antecedents of Objectively Diagnosed Diffuse White Matter Abnormality in Very Preterm Infants. Pediatr Neurol. 2020;106:56-62.

17. Hart AR, Smith MF, Rigby AS, Wallis LI, Whitby EH. Appearances of diffuse excessive high signal intensity (DEHSI) on MR imaging following preterm birth. Pediatr Radiol. 2010;40(8):1390-1396.

18. Calloni SF, Cinnante CM, Bassi L, et al. Neurodevelopmental outcome at 36 months in very low birth weight premature infants with MR diffuse excessive high signal intensity (DEHSI) of cerebral white matter. Radiol Med. 2015;120(11):1056-1063.

19. Morel B, Antoni G, Teglas JP, Bloch I, Adamsbaum C. Neonatal brain MRI: how reliable is the radiologist's eye? Neuroradiology. 2016;58(2):189-193. 
20. He L, Parikh NA. Automated detection of white matter signal abnormality using T2 relaxometry: application to brain segmentation on term MRI in very preterm infants. Neuroimage. 2013;64:328-340.

21. He L, Parikh NA. Atlas-guided quantification of white matter signal abnormalities on term-equivalent age MRI in very preterm infants: findings predict language and cognitive development at two years of age. PLoS One. 2013;8(12):e85475.

22. Parikh NA, Lasky RE, Kennedy KA, McDavid G, Tyson JE. Perinatal factors and regional brain volume abnormalities at term in a cohort of extremely low birth weight infants. PLoS One. 2013;8(5):e62804.

23. Tamm L, Patel M, Peugh J, Kline-Fath BM, Parikh NA, Cincinnati Infant Neurodevelopment Early Prediction Study. Early brain abnormalities in infants born very preterm predict under-reactive temperament. Early Hum Dev. 2020;144:104985.

24. Friston KJ, Holmes AP, Worsley KJ, Poline J-P, Frith CD, Frackowiak RSJ. Statistical parametric maps in functional imaging: A general linear approach. Human Brain Mapping. $1994 ; 2(4): 189-210$.

25. Kidokoro H, Neil JJ, Inder TE. New MR imaging assessment tool to define brain abnormalities in very preterm infants at term. AJNR Am J Neuroradiol. 2013;34(11):2208-2214. 26. Nelson KB, Ellenberg JH. Antecedents of cerebral palsy. Multivariate analysis of risk. $\mathrm{N}$ Engl J Med. 1986;315(2):81-86.

27. Doyle LW, Davis PG, Morley CJ, McPhee A, Carlin JB, Investigators DS. Low-dose dexamethasone facilitates extubation among chronically ventilator-dependent infants: a multicenter, international, randomized, controlled trial. Pediatrics. 2006;117(1):75-83.

28. Schmidt B, Asztalos EV, Roberts RS, et al. Impact of bronchopulmonary dysplasia, brain injury, and severe retinopathy on the outcome of extremely low-birth-weight infants at 18 months: results from the trial of indomethacin prophylaxis in preterms. JAMA. 2003;289(9):1124-1129. 
29. Schmidt B, Davis PG, Asztalos EV, Solimano A, Roberts RS. Association between severe retinopathy of prematurity and nonvisual disabilities at age 5 years. JAMA. $2014 ; 311(5): 523-525$.

30. Kline JE, Illapani VSP, He L, Altaye M, Parikh NA. Retinopathy of Prematurity and Bronchopulmonary Dysplasia are Independent Antecedents of Cortical Maturational Abnormalities in Very Preterm Infants. Sci Rep. 2019;9(1):19679.

31. Stoll BJ, Hansen NI, Bell EF, et al. Trends in Care Practices, Morbidity, and Mortality of Extremely Preterm Neonates, 1993-2012. JAMA. 2015;314(10):1039-1051.

32. Doyle LW, Halliday HL, Ehrenkranz RA, Davis PG, Sinclair JC. An update on the impact of postnatal systemic corticosteroids on mortality and cerebral palsy in preterm infants: effect modification by risk of bronchopulmonary dysplasia. J Pediatr. 2014;165(6):1258-1260.

33. Schmidt B, Roberts RS, Anderson PJ, et al. Academic Performance, Motor Function, and Behavior 11 Years After Neonatal Caffeine Citrate Therapy for Apnea of Prematurity: An 11-Year Follow-up of the CAP Randomized Clinical Trial. JAMA Pediatr. 2017;171(6):564-572.

34. Rhein LM, Dobson NR, Darnall RA, et al. Effects of caffeine on intermittent hypoxia in infants born prematurely: a randomized clinical trial. JAMA Pediatr. 2014;168(3):250-257. 35. Furman D, Chang J, Lartigue L, et al. Expression of specific inflammasome gene modules stratifies older individuals into two extreme clinical and immunological states. Nat Med. $2017 ; 23(2): 174-184$.

36. Iris M, Tsou PS, Sawalha AH. Caffeine inhibits STAT1 signaling and downregulates inflammatory pathways involved in autoimmunity. Clin Immunol. 2018;192:68-77.

37. Schmidt B, Roberts RS, Davis P, et al. Caffeine therapy for apnea of prematurity. N Engl J Med. 2006;354(20):2112-2121.

38. Anderson JW, Johnstone BM, Remley DT. Breast-feeding and cognitive development: a meta-analysis. Am J Clin Nutr. 1999;70(4):525-535. 
39. Horwood LJ, Darlow BA, Mogridge N. Breast milk feeding and cognitive ability at 7-8 years. Arch Dis Child Fetal Neonatal Ed. 2001;84(1):F23-27.

40. Belfort MB, Anderson PJ, Nowak VA, et al. Breast Milk Feeding, Brain Development, and Neurocognitive Outcomes: A 7-Year Longitudinal Study in Infants Born at Less Than 30 Weeks' Gestation. J Pediatr. 2016;177:133-139 e131.

41. Isaacs EB, Fischl BR, Quinn BT, Chong WK, Gadian DG, Lucas A. Impact of breast milk on intelligence quotient, brain size, and white matter development. Pediatr Res. 2010;67(4):357362.

42. Pogribna U, Burson K, Lasky RE, Narayana PA, Evans PW, Parikh NA. Role of diffusion tensor imaging as an independent predictor of cognitive and language development in extremely low-birth-weight infants. AJNR Am J Neuroradiol. 2014;35(4):790-796.

43. Blesa M, Sullivan G, Anblagan D, et al. Early breast milk exposure modifies brain connectivity in preterm infants. Neuroimage. 2019;184:431-439.

44. Mehrabani D, Gowen CW, Jr., Kopelman AE. Association of pneumothorax and hypotension with intraventricular haemorrhage. Arch Dis Child. 1991;66(1 Spec No):48-51.

45. Pishva N, Parsa G, Saki F, Saki M, Saki MR. Intraventricular hemorrhage in premature infants and its association with pneumothorax. Acta Med Iran. 2012;50(7):473-476.

46. García-Muñoz Rodrigo F, Urquía Martí L, Galán Henríquez G, et al. Perinatal risk factors for pneumothorax and morbidity and mortality in very low birth weight infants. The Journal of Maternal-Fetal \& Neonatal Medicine. 2017;30(22):2679-2685.

47. Laptook AR, O'Shea TM, Shankaran S, Bhaskar B, Network NN. Adverse neurodevelopmental outcomes among extremely low birth weight infants with a normal head ultrasound: prevalence and antecedents. Pediatrics. 2005;115(3):673-680.

48. Temesvari P, Hencz P, Joo F, Eck E, Szerdahelyi P, Boda D. Modulation of the bloodbrain barrier permeability in neonatal cytotoxic brain edema: laboratory and morphological 
findings obtained on newborn piglets with experimental pneumothorax. Biol Neonate. $1984 ; 46(4): 198-208$.

49. Brann BSt, Mayfield SR, Goldstein M, On W, Stonestreet BS. Cardiovascular effects of hypoxia/hypercarbia and tension pneumothorax in newborn piglets. Crit Care Med. 1994;22(9):1453-1460.

50. de Bruine FT, van den Berg-Huysmans AA, Leijser LM, et al. Clinical implications of MR imaging findings in the white matter in very preterm infants: a 2-year follow-up study. Radiology. $2011 ; 261(3): 899-906$.

51. Tremblay S, Miloudi K, Chaychi S, et al. Systemic inflammation perturbs developmental retinal angiogenesis and neuroretinal function. Invest Ophthalmol Vis Sci. 2013;54(13):81258139.

52. Hong HK, Lee HJ, Ko JH, et al. Neonatal systemic inflammation in rats alters retinal vessel development and simulates pathologic features of retinopathy of prematurity. $\mathrm{J}$ Neuroinflammation. 2014;11:87.

53. Sood BG, Madan A, Saha S, et al. Perinatal systemic inflammatory response syndrome and retinopathy of prematurity. Pediatr Res. 2010;67(4):394-400.

54. Klinger G, Levy I, Sirota L, et al. Outcome of early-onset sepsis in a national cohort of very low birth weight infants. Pediatrics. 2010;125(4):e736-740.

55. Chen ML, Allred EN, Hecht JL, et al. Placenta microbiology and histology and the risk for severe retinopathy of prematurity. Invest Ophthalmol Vis Sci. 2011;52(10):7052-7058.

56. Baud O, Maury L, Lebail F, et al. Effect of early low-dose hydrocortisone on survival without bronchopulmonary dysplasia in extremely preterm infants (PREMILOC): a double-blind, placebo-controlled, multicentre, randomised trial. Lancet. 2016;387(10030):1827-1836.

57. Zeng L, Tian J, Song F, et al. Corticosteroids for the prevention of bronchopulmonary dysplasia in preterm infants: a network meta-analysis. Arch Dis Child Fetal Neonatal Ed. 2018;103(6):F506-F511. 
medRxiv preprint doi: https://doi.org/10.1101/2020.08.01.20166488; this version posted August 4, 2020. The copyright holder for this preprint (which was not certified by peer review) is the author/funder, who has granted medRxiv a license to display the preprint in perpetuity.

All rights reserved. No reuse allowed without permission.

58. Doyle LW, Cheong JL, Ehrenkranz RA, Halliday HL. Early ( $<8$ days) systemic postnatal corticosteroids for prevention of bronchopulmonary dysplasia in preterm infants. Cochrane Database Syst Rev. 2017;10:CD001146.

59. Suresh GK, Davis JM, Soll RF. Superoxide dismutase for preventing chronic lung disease in mechanically ventilated preterm infants. Cochrane Database Syst Rev. 2001(1):CD001968.

60. Askie LM, Darlow BA, Davis PG, et al. Effects of targeting lower versus higher arterial oxygen saturations on death or disability in preterm infants. Cochrane Database Syst Rev. 2017;4:CD011190.

61. Hanson LA, Hahn-Zoric M, Berndes M, et al. Breast feeding: overview and breast milk immunology. Acta Paediatr Jpn. 1994;36(5):557-561.

62. Walker A. Breast milk as the gold standard for protective nutrients. J Pediatr. 2010;156(2 Suppl):S3-7. 

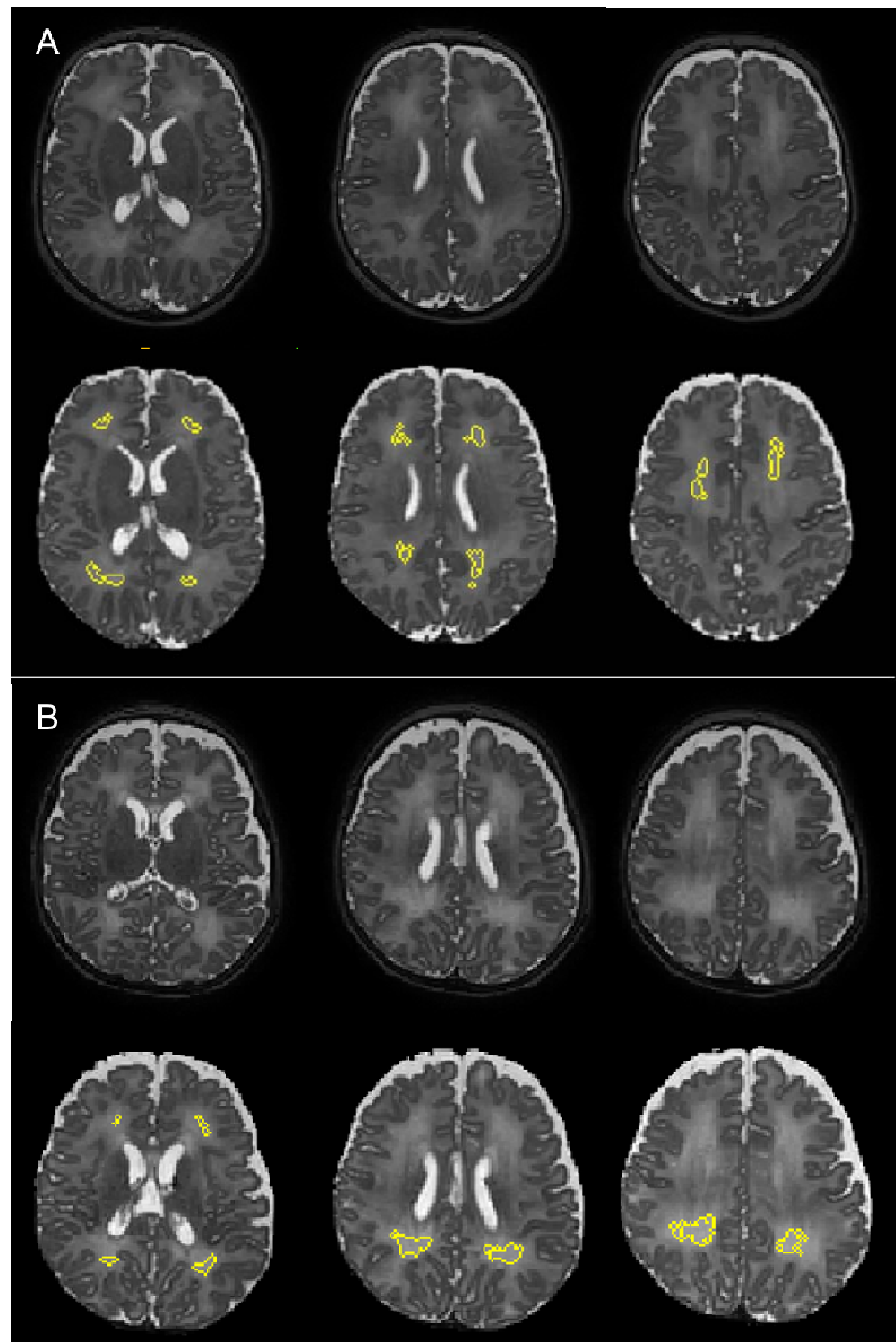
medRxiv preprint doi: https://doi.org/10.1101/2020.08.01.20166488; this version posted August 4, 2020. The copyright holder for this preprint (which was not certified by peer review) is the author/funder, who has granted medRxiv a license to display the preprint in perpetuity.

All rights reserved. No reuse allowed without permission.

Figure 1. Semiautomated segmentation of diffuse white matter abnormality (DWMA) in the periventricular and central white matter. A. Top three panels display raw axial T2weighed magnetic resonance images through the central part of the brain from a 28 week very preterm boy. Higher signal intensity can be appreciated in the white matter from the surrounding gray matter. Bottom three panels display the segmented (yellow) moderate degree of DWMA white matter regions. B. Top three panels display raw axial T2-weighed MR images from a 30 week very preterm boy. Higher signal intensity can be appreciated in the periventricular and central white matter from the surrounding gray matter. Bottom three panels display the segmented (yellow) severe DWMA. 
Table 1. Distributions of important antenatal, intrapartum, and postnatal clinical factors prior to MRI at term-equivalent age in a multicenter cohort of very preterm infants.

\begin{tabular}{|c|c|}
\hline Perinatal Clinical Factors ${ }^{\star}$ & All Infants $(\mathrm{N}=377)$ \\
\hline Maternal diabetes & $44(11.7 \%)$ \\
\hline Histologic chorioamnionitis† & $104(30.6 \%)$ \\
\hline Maternal progesterone therapy & $73(19.4 \%)$ \\
\hline Antenatal steroids (any) & $348(92.3 \%)$ \\
\hline Antenatal magnesium therapy & $316(83.8 \%)$ \\
\hline Gestational age (weeks), median (range) & $29.7(23.0-32.9)$ \\
\hline Birth weight (grams), mean (SD) & $1302(452)$ \\
\hline Male sex, $\mathrm{n}(\%)$ & $198(52.5 \%)$ \\
\hline Apgar score $<5$ at 5 minutes§ & $48(12.9 \%)$ \\
\hline Pneumothorax & $25(6.6 \%)$ \\
\hline Prophylactic indomethacin therapy & $15(4.0 \%)$ \\
\hline Cyclooxygenase inhibitor therapy & $36(9.6 \%)$ \\
\hline Caffeine therapy & $266(70.6 \%)$ \\
\hline Duration of caffeine therapy in infants with severe BPD, median (range) & $62(0-89)$ \\
\hline Lowest mean blood pressure in first 24 hours $(\mathrm{mm} \mathrm{Hg})$, mean (SD) ${ }^{\star \star}$ & $31.4(7.4)$ \\
\hline Transitional hypotension requiring therapy & $15(4.0 \%)$ \\
\hline Surgery for NEC or SIP & $9(2.4 \%)$ \\
\hline Culture positive late onset sepsis & $41(10.9 \%)$ \\
\hline Patent ductus arteriosus & $94(24.9 \%)$ \\
\hline Severe ROP & $18(4.8 \%)$ \\
\hline BPD (any severity) & $154(40.9 \%)$ \\
\hline Severe BPD & $65(17.2 \%)$ \\
\hline Postnatal dexamethasone for severe BPD & $31(8.2 \%)$ \\
\hline Surgery requiring general anesthesia & $42(11.1 \%)$ \\
\hline White matter abnormality score on term MRI, median (range) & $1(0-15)$ \\
\hline PMA at MRI scan (weeks), mean (SD) & $42.7(1.4)$ \\
\hline
\end{tabular}


Table 2. Final multivariable linear regression model displaying the coefficients of several clinical antecedents that were associated with the development of diffuse white matter abnormality (DWMA), which was objectively-defined on structural brain MRI at term-equivalent age.

\begin{tabular}{|l|c|c|}
\hline Clinical Antecedent & Coefficient (95\% Cl) & $\boldsymbol{P}$ Value \\
\hline Pneumothorax & $0.0328(0.0038,0.0618)$ & 0.027 \\
\hline Severe bronchopulmonary dysplasia (BPD) & $0.0570(0.0141,0.0999)$ & 0.009 \\
\hline Dexamethasone for severe BPD & $-0.0551(-0.0928,-0.0174)$ & 0.004 \\
\hline Duration of caffeine for severe BPD & $-0.0008(-0.0016,-0.0001)$ & 0.029 \\
\hline Severe retinopathy of prematurity & $0.0659(0.0305,0.1014)$ & $<0.001$ \\
\hline Exclusive maternal milk at NICU discharge & $-0.0237(-0.0472,-0.0002)$ & 0.049 \\
\hline White matter abnormality score on term MRI & $-0.0047(-0.0081,-0.0014)$ & 0.006 \\
\hline Male sex & $0.0151(0.0006,0.0296)$ & 0.041 \\
\hline Postmenstrual age at MRI scan & $-0.0266(-0.0322,-0.0211)$ & $<0.001$ \\
\hline Center & $-0.0098(-0.0173,-0.0023)$ & 0.011 \\
\hline
\end{tabular}

*Normalized volume of DWMA was transformed by taking its cubic root. Therefore, the coefficients represent approximately the cubic root change in DWMA volume for one unit change in the clinical antecedent, while holding the other independent variables constant. 